\title{
Expression of Bacterial Blight Resistance in Brassica Leafy Greens Under Field Conditions and Inheritance of Resistance in a Brassica juncea Source
}

W. P. Wechter, United States Department of Agriculture-Agricultural Research Service (USDA-ARS), U.S. Vegetable Laboratory, Charleston, SC 29414; A. P. Keinath, Clemson University, Coastal Research and Education Center, Charleston, SC 29414; M. McMillan, USDA-ARS, U.S. Vegetable Laboratory, Charleston; J. P. Smith, Clemson University, Cooperative Extension Service, Lexington, SC, 29072; and M. W. Farnham, USDA-ARS, U.S. Vegetable Laboratory, Charleston

\begin{abstract}
Wechter, W. P., Keinath, A. P., McMillan, M., Smith, J. P., and Farnham, M. W. 2013. Expression of bacterial blight resistance in Brassica leafy greens under field conditions and inheritance of resistance in a Brassica juncea source. Plant Dis. 97:131-137.

Brassica leafy greens are one of the most economically important vegetable commodity groups grown in the southeastern United States, and more than 28,000 metric tons of these crops are harvested in the United States annually. Collard and kale (Brassica oleracea Acephala group), mustard green (B. juncea), and turnip green (B. rapa) are the most commonly planted members of the brassica leafy greens group. In the last 10 years, numerous occurrences of bacterial blight on these leafy vegetables have been reported in several states. One of the pathogens responsible for this blight is designated Pseudomonas cannabina pv. alisalensis. Two B. rapa (G30710 and G30499) and two B. juncea

(PI418956 and G30988) plant introductions (PIs) that exhibited moderate to high levels of resistance to this pathogen in greenhouse studies were tested for field resistance in comparison with eight commercial cultivar representatives of turnip green, mustard green, collard, and kale. The two $B$. juncea PIs and one of the $B$. rapa PIs (G30499) were found to have significantly less disease than all tested cultivars except 'Southern Curled Giant' mustard green (B. juncea) and 'Blue Knight' kale (B. oleracea). Inheritance of resistance studies performed with populations derived from the resistant G30988 and two susceptible PIs provided some evidence that resistance may be controlled by a single recessive gene.
\end{abstract}

\begin{abstract}
"Brassica leafy greens" is a general term that encompasses a number of different, commonly consumed members of the closely related species Brassica juncea L., B. rapa L., and B. oleracea L. Brassica leafy greens include turnip green (B. rapa), mustard green (B. juncea), and collard and kale (B. oleracea). More than 28,000 metric tons of these vegetables are produced annually in the United States, with a value of $\$ 37$ million, and $70 \%$ of this is produced in the southeastern states, making brassica leafy greens a vital part of southern agriculture (16). Because these crops are grown for the foliar portion of the plant, any spotting, chlorosis, or other blemishes of harvested leaves can result in rejection of product and, thus, loss of sales and income.

Numerous fungal and bacterial phytopathogens attack these crops, and all of them can cause leaf damage. Many of the more serious fungal foliar pathogens such as Alternaria spp., powdery mildew, and downy mildew are effectively controlled by the use of available fungicides (15). The same also is true for many of the insect pests. Unfortunately, bacterial pathogens have been more difficult to control with available agricultural chemicals. In fact, two management guides $(7,13)$ make no mention of bacterial disease control measures, while a third (14) suggests crop rotation and copper as the primary controls of bacterial leaf pathogens. Although the brassica leafy greens includes representatives of different species, the different species are typically grown in adjoining fields, if not adjoining blocks in the same field. Thus, it is important to understand the relative susceptibility of cultivars across the different species, because spread of any pest or pathogen between them is highly likely.

In spring 2001, major growers of brassica leafy greens in South Carolina reported a severe outbreak of leaf spotting and blight. The
\end{abstract}

Corresponding author: W. P. Wechter, E-mail: Pat.Wechter@ars.usda.gov

Accepted for publication 29 July 2012.

http://dx.doi.org/10.1094/PDIS-02-12-0220-RE

This article is in the public domain and not copyrightable. It may be freely reprinted with customary crediting of the source. The American Phytopathological Society, 2013. pathogen was originally reported to be Pseudomonas syringae pv. maculicola, the causal agent of peppery leaf spot in Brassica spp. $(6,17)$. The pathogen subsequently was determined to be $P$. syringae pv. alisalensis (18). P. syringae pv. alisalensis was first described in broccoli raab in California (4). The pathogen has recently been renamed $P$. cannabina pv. alisalensis (2). In the past few years, $P$. cannabina pv. alisalensis has been repeatedly identified as a bacterial pathogen which causes blight on brassica leaves. This disease has caused significant reductions in marketable yield in brassica leafy greens due to damaging symptoms of leaf chlorosis and necrosis, as well as reduced plant growth. Presently, $P$. cannabina pv. alisalensis has been reported on numerous crops in several states $(1,3,8-11,18)$. In South Carolina, one of the largest brassica leafy greens-producing states, growers of turnip and mustard greens have incurred recent losses due to $P$. cannabina pv. alisalensis of over $\$ 1.7$ million per year, or $24 \%$ of total production (15). Previous recommended practices to control bacterial blight have been crop rotation and reduction in overhead irrigation, practices which have never proved very effective. The use of copper hydroxide or acibenzolar-S-methyl also has been relatively ineffective (5). Although no conclusive evidence as to the seedborne nature of this pathogen has been reported, closely related species of Pseudomonas have been shown to be seedborne and, thus, "clean seed" should be included in a disease management strategy.

We previously reported the identification of several $P$. cannabina pv. alisalensis-resistant $B$. rapa and $B$. juncea plant introductions (PIs) from a controlled inoculation and screening of 672 accessions from the U.S. PI collection (17). Two B. rapa (G30710 and G30499) and two B. juncea (PI418956 and G30988) selections demonstrated the highest resistance. A random sample of these accessions were taken through two successive self-pollinations $\left(S_{2}\right)$ to form seed lots for subsequent testing. The objectives of this study were to (i) evaluate field resistance of four PIs of $B$. rapa and $B$. juncea, previously identified as resistant to $P$. cannabina pv. alisalensis in greenhouse tests, along with eight commercial cultivars; and (ii) determine genetic inheritance of resistance exhibited by the most resistant PI, G30988. 


\section{Materials and Methods}

Plant materials. B. juncea and B. rapa accessions (PIs) were originally obtained from the United States Department of Agriculture-Agricultural Research Service (USDA-ARS), North Central Regional Plant Introduction Station in Ames, IA, and from the Northeast Regional Plant Introduction Station, USDA-ARS Plant Genetic Resources Unit in Geneva, NY. B. juncea PI418956 and G30988 and B. rapa G30499 and G30710 were found in a previous study to have significant levels of resistance to bacterial blight caused by $P$. cannabina pv. alisalensis (17). Initial observations of these accessions in the greenhouse indicated that they are highly uniform in plant type and disease response and also self compatible. Approximately 15 individuals of each of the resistant accessions were allowed to self-pollinate in a greenhouse and produce $S_{1}$ seed. Selfing was repeated another year to generate $S_{2}$ seed. $S_{2}$ seed from individual plants was combined to generate a composite seed lot for the field tests The commercial brassica leafy green cultivars 'Tendergreen' (B. rapa spinach mustard), 'Alamo' (B. rapa turnip green), 'Topper' (B. rapa turnip green), 'Florida Broadleaf' (B. juncea mustard green), 'Southern Giant Curled' (B. juncea mustard green), 'Blue Max' (B. oleracea collard), 'Top Bunch' (B. oleracea collard), and 'Blue Knight' (B. oleracea kale), obtained from Abbott and Cobb Seed Co., also were included in the field trials.

Bacterial isolates. $P$. cannabina pv. alisalensis isolate T3C was collected in 2001 from Topper turnip green in Lexington, SC (6). This isolate has been shown to be highly virulent and to induce consistent infection over a range of temperatures in greenhouse and growth-chamber studies, as well as in the field (17).

Field trials. Seed of the 12 B. juncea, B. rapa, and B. oleracea entries described above were seeded to 200-cell Speedling trays (Speedling Inc.) in Fafard 3B medium (Conrad Fafard Inc.). Seedlings were grown in a greenhouse for approximately 4 weeks before transplanting. Three days before transplanting to the field, trays were moved outdoors.

Field trials were performed in Charleston, SC in fall 2010 and 2011. Each experiment was conducted on a different field at the Clemson University Coastal Research and Education Center. In each case, the soil type was a Charleston loamy fine sand with a $\mathrm{pH}$ of 6.8. The field was disked twice, and 15-0-15 (N-P-K) fertilizer at $336 \mathrm{~kg} / \mathrm{ha}$ was applied to the field prior to forming the beds. Beds were raised, $46 \mathrm{~cm}$ wide on $91-\mathrm{cm}$ centers. Transplants were set in two rows per bed and spaced $15 \mathrm{~cm}$ apart within rows. In total, 40 transplants per plot were used. Plants were side-dressed with $15.5-0-0$ calcium nitrate at $336 \mathrm{~kg} / \mathrm{ha} 5$ weeks after transplanting. The experimental design was a randomized complete block with four replications.

In both field trials, all plants were inoculated 3 weeks after transplanting by spraying them with a $1 \times 10^{8} \mathrm{CFU} / \mathrm{ml}$ suspension of $P$. cannabina pv. alisalensis isolate $\mathrm{T} 3 \mathrm{C}$ using a $\mathrm{CO}_{2}$-backpack sprayer with double boom attachment and a calibrated spray rate of approximately $50 \mathrm{ml}$ of inoculum per plot. For these inoculations, T3C was grown on Pseudomonas Agar F medium (Difco, Becton Dickenson and Co.) for $16 \mathrm{~h}$ at $27^{\circ} \mathrm{C}$. Cells were then harvested and resuspended in sterile distilled water. The cell suspension was adjusted with sterile distilled water to an optical density at $600 \mathrm{~nm}$ $\left(\mathrm{OD}_{600}\right)$ of 0.6 (approximately $1 \times 10^{8} \mathrm{CFU} / \mathrm{ml}$ ) using a BioPhotometer 6136 (Eppendorf). The surfactant Latron B-1956 (Dow Agrosciences LLC) was added to the cell suspension at 3.2 $\mu \mathrm{l} / \mathrm{ml}$ to enhance leaf coverage. To help establish the pathogen, leaf wetness was maintained by using Senninger low-pressure miniwobbler sprinklers to produce a mist in the evening for 30 to 60 min each day until harvest. To prevent Cercospora leaf spot and white spot, pyraclostrobin and cyprodinil plus fludioxonil were each applied twice at labeled rates. Fourteen days post inoculation, each plot was rated visually by two researchers for percent leaf surface area with symptoms of bacterial blight using a 0 -to- $100 \%$ scale in $2.5 \%$ increments. The two ratings were averaged and then scored as that average or the next higher increment if the average was not a 2.5 increment. The day of or day after rating, all plants were harvested from a $1-\mathrm{m}$ section of the right-hand row in each plot. Leaves were removed from the harvested plants and sorted into asymptomatic (healthy) or diseased groups that were weighed separately. Leaves with any symptoms of bacterial blight were considered diseased.

Inheritance of resistance in G30988 to $P$. cannabina pv. alisalensis. Two segregating populations for use in inheritance studies were generated by crossing the highly resistant $B$. juncea $\mathrm{G} 30988$ (as the female) with the highly susceptible $B$. juncea PI212594, as well as the highly susceptible $B$. juncea PI432377 (17), to generate $\mathrm{F}_{1}$ populations. PI212594 and PI432377 were found to be more susceptible than the turnip green Topper (17). Both resistant and susceptible parental lines were allowed to self-pollinate in a controlled greenhouse environment to the $S_{2}$ generation prior to performing subsequent crosses. $\mathrm{S}_{2}$ lines appeared to be highly uniform. The $F_{1}$ plants were self-pollinated to generate $F_{2}$ seed. In addition, reciprocal backcrosses were generated between the $F_{1}$ and the two respective parents used to form each population.

In the initial disease assay, we included 8 plants of the susceptible parent (PI212594), 8 plants of the resistant parent (G30988), 8 $\mathrm{F}_{1}(\mathrm{G} 30988 \times \mathrm{PI} 212594)$ plants, $70 \mathrm{~F}_{2}$ individuals, 28 resistant backcross $([\mathrm{G} 30988 \times$ PI212594] $\times$ G30988) individuals, and 39 susceptible backcross $([\mathrm{G} 30988 \times$ PI212594] $\times$ PI212594) individuals. The second assay of the same populations included 10 plants each of the susceptible and resistant parents, $10 \mathrm{~F}_{1}$ plants, $107 \mathrm{~F}_{2}$ individuals, and 55 individuals of each of the two backcrosses. The third assay was run on a different set of crosses and backcrosses, including 8 plants of the resistant parent (G30988), 8 plants of the susceptible parent (PI432377), $8 F_{1}(G 30988 \times$ PI432377) plants, $80 \quad \mathrm{~F}_{2}$ individuals, 40 resistant backcross $([\mathrm{G} 30988 \times$ PI432377] $\times$ G30988) individuals, and 40 susceptible backcross $([\mathrm{G} 30988 \times$ PI432377] $\times$ PI432377) individuals. Differences in the number of plants used in each test were a function of germination rates of the seed as well as seed supplies, which are generated by self pollinations.

Seed were sown in Metro-Mix 200 soilless mix (The Scott's Co.) in 5-by-5-cm pots. Plants were thinned to one plant per pot at 10 days after seeding and then allowed to grow in the greenhouse. At the third-true-leaf stage (approximately 3 weeks after seeding), the plants were inoculated as follows. T3C was grown on Pseudomonas Agar F medium (Difco, Becton Dickenson and Co.) for $16 \mathrm{~h}$ at $27^{\circ} \mathrm{C}$. Cells were then harvested and resuspended in sterile distilled water. The cell suspension was adjusted with sterile distilled water to an $\mathrm{OD}_{600}$ of 0.6 (approximately $1 \times 10^{8} \mathrm{CFU} / \mathrm{ml}$ ) using a BioPhotometer 6136 (Eppendorf). The surfactant Latron B-1956 (Dow Agrosciences LLC) was added to the cell suspension at 3.2 $\mu \mathrm{l} / \mathrm{ml}$ to enhance leaf coverage. The suspension was applied to the leaves of each plant using a Paasche model-H airbrush sprayer (Paasche Airbrush Company) at approximately $170 \mathrm{kPa}$ until the leaf surface was uniformly covered. Inoculated plants were placed in a humidity chamber at $100 \%$ relative humidity for $16 \mathrm{~h}$ and then transferred to the greenhouse bench for 10 days prior to rating for disease. Greenhouse temperatures were 27 to $32^{\circ} \mathrm{C}$.

The two most severely infected leaves from each plant were evaluated. Specifically, each leaf was rated for the percentage of diseased leaf area by visual estimation. An average was taken between the two leaves and used as the final individual plant rating. Analysis of the two G30988 × PI212594 populations for homogeneity frequencies between the two separate tests indicated that there were no significant differences between the two runs; therefore, all data were combined.

Statistical analysis. Healthy weight yields from 2010 and 2011 were combined for the commercial cultivars and three of the PIs belonging to $B$. juncea and B. rapa. The Mixed procedure of SAS (version 9.1; SAS Institute, Inc.), with year and variety as fixed effects, showed no year-germplasm interaction for the plants belonging to those two species $(P=0.881)$, allowing data to be combined. Foliar disease ratings and yield data were subjected to analysis of variance using a general linear models procedure of 
SAS (version 9.1; SAS Institute, Inc.). Disease severity was transformed by calculating the square root before analysis of variance to reduce inequality of variances among treatments. For the inheritance studies, a $\chi^{2}$ analysis was used to compare the numbers of resistant and susceptible individuals that were observed with the numbers expected with a single recessive-gene inheritance model.

\section{Results}

Field trials. Average maximum and minimum temperatures were 28.8 and $15.9^{\circ} \mathrm{C}$, respectively, during the 2010 trial and 26.7 and $16.6^{\circ} \mathrm{C}$, respectively, during the 2011 trial. Rainfall for the trial period for the two years was 18.8 and $13.9 \mathrm{~cm}$, respectively, with no severe rain events during either test period. The use of a misting system kept the moisture conditions of the leaves fairly consistent. In general, conditions between the 2 years were relatively similar.

Although bacterial blight developed on all individuals tested in the 2010 and 2011 field trials, accessions and cultivars differed significantly in the severity of disease each exhibited. In 2010, Alamo and Topper (B. rapa turnip green), Tendergreen (B. rapa spinach mustard), Blue Max, and Top Bunch (B. oleracea collard) were among the most severely diseased entries. The same cultivars, found to be the most susceptible in the 2010 trials, were also the most susceptible to bacterial blight in the 2011 trials (Table 1). Three of the PI accessions (G30499, PI418956, and G30988) were more resistant than all commercial cultivars except for Blue Knight kale and Southern Giant Curled mustard green in both the 2010 and 2011 trials. One PI, G30710 (B. rapa bok choy-like), originally selected as putatively resistant to $P$. cannabina pv. alisalensis (17), was found to be susceptible to bacterial blight in both field trials. Of particular interest in the field trials, the mustard green accession G30988 exhibited the lowest incidence of disease in both years (Table 1). In 2011, it exhibited significantly fewer disease symptoms than all other accessions or cultivars.
Due to differences in plant size and leaf density of the three $B$. oleracea cultivars (collard and kale), these lines were not incorporated in the combined healthy weight analysis. In addition, G30710 was not a phenotypically uniform accession, segregating for mustard-like and Bok choy-like individuals; therefore, it also could not be used for healthy weight analysis. Averaged over both trials, the

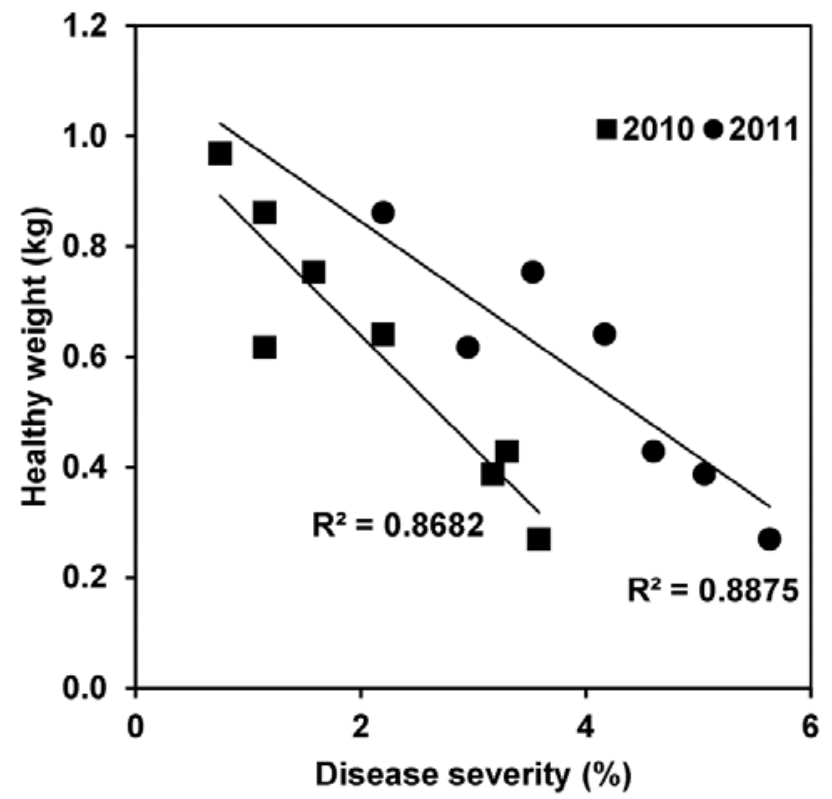

Fig. 1. Correlation between percent disease severity and healthy weight among eight brassica leafy green accessions inoculated with Pseudomonas cannabina pv. alisalensis in the field. Plots were rated by percent disease severity based on a $2.5 \%$ scale. Disease severity was square root transformed due to non-normal distribution.

Table 1. Mean disease severity ratings (percent leaf affected, averaged for plot) of bacterial blight symptoms observed on 12 brassica leafy green accessions grown in field trials in fall 2010 and 2011

\begin{tabular}{lllcc}
\hline & & & \multicolumn{2}{c}{ Disease severity (\%) $^{\mathbf{y}}$} \\
\cline { 3 - 5 } Cultivar or PI & \multicolumn{1}{c}{ Species } & \multicolumn{1}{c}{ Crop } & Fall 2010 & Fall 2011 \\
\hline Blue Max & Brassica oleracea & Collard & $10.61 \mathrm{ab}$ & $36.68 \mathrm{a}$ \\
Tendergreen & B. rapa & Spinach mustard & $12.84 \mathrm{a}$ & $31.72 \mathrm{ab}$ \\
Top Bunch & B. oleracea & Collard & $9.61 \mathrm{abc}$ & $26.84 \mathrm{bc}$ \\
Topper & B. rapa & Turnip green & $10.07 \mathrm{ab}$ & $25.52 \mathrm{bc}$ \\
Alamo & B. rapa & Turnip green & $10.88 \mathrm{ab}$ & $21.16 \mathrm{dc}$ \\
G 30710 & B. rapa & Bok choy-like & $6.19 \mathrm{bc}$ & $17.45 \mathrm{de}$ \\
Florida Broadleaf & B. juncea & Mustard green & $4.83 \mathrm{~cd}$ & $17.35 \mathrm{de}$ \\
Southern Giant Curled & B. juncea & Mustard green & $2.50 \mathrm{de}$ & $12.44 \mathrm{ef}$ \\
PI 418956 & B. juncea & Mustard green & $1.31 \mathrm{e}$ & $8.70 \mathrm{f}$ \\
G 30499 & B. rapa & Chinese cabbage-like & $1.31 \mathrm{e}$ & $4.83 \mathrm{~g}$ \\
Blue Knight & B. oleracea & Kale & $1.71 \mathrm{de}$ & $4.74 \mathrm{~g}$ \\
G 30988 & B. juncea & Mustard green & $0.56 \mathrm{e}$ & $0.56 \mathrm{~h}$ \\
\hline
\end{tabular}

y Percent disease severity was analyzed as square-root transformed due to non-normal distribution but the non-transformed values are presented here. Plots were rated by percent disease severity based on the average percent of leaf area showing bacterial leaf blight symptoms within the plot. Ratings were based on a 1 -to- $100 \%$ scale in $2.5 \%$ increments. Means with the same letter are not significantly different, Waller-Duncan $k$ ratio $t$ test, $k=500$ (or $P=0.01$ ).

${ }^{\mathrm{z}}$ Cultivar or plant introduction (PI) line.

Table 2. Mean healthy leaf weight of eight brassica leafy green accessions across two different field trials (fall 2010 and 2011)

\begin{tabular}{lllc}
\hline Cultivar or PI & Species & Crop & Weight $^{\mathbf{y}}(\mathbf{k g})^{\mathbf{z}}$ \\
\hline Tendergreen & Brassica rapa & Spinach mustard & $0.25 \mathrm{e}$ \\
Topper & B. rapa & Turnip green & $0.37 \mathrm{e}$ \\
Alamo & B. rapa & Turnip green & $0.41 \mathrm{de}$ \\
PI 418956 & B. juncea & Mustard green & $0.60 \mathrm{~cd}$ \\
Florida Broadleaf & B. juncea & Mustard green & $0.62 \mathrm{~cd}$ \\
Southern Giant Curled & B. juncea & Mustard green & $0.74 \mathrm{bc}$ \\
G 30499 & B. rapa & Chinese cabbage-like & $0.84 \mathrm{ab}$ \\
G 30988 & B. juncea & Mustard green & $0.95 \mathrm{a}$ \\
\hline
\end{tabular}

y Cultivar or plant introduction (PI) line.

${ }^{\mathrm{z}}$ Healthy weight fall 2010 and $2011=$ combined plot averages of healthy leaves harvested in 2010 and 2011. Means with the same letter are not significantly different, Waller-Duncan $k$ ratio $t$ test, $k=500$ (or $P=0.01$ ). 
two resistant PI lines G30499 and G30988 had the highest mean healthy leaf weight (Table 2). B. juncea G30988 differed significantly from the two cultivars of mustard green and B. rapa G30499 differed significantly in healthy leaf weight from the two cultivars of turnip green and spinach mustard. The healthy leaf weight of $B$. juncea PI418956 was significantly greater than Tendergreen and Topper but significantly less than the more resistant $B$. juncea G30988. There was a strong inverse correlation $(P<0.01)$ between disease severity and healthy leaf weight in both $2010(r=0.87)$ and $2011(r=0.89)$ (Fig. 1). It is again noteworthy that the most re- sistant (e.g., lowest disease severity) accession G30988 had the highest healthy leaf weight compared with all others.

Inheritance of resistance to $P$. cannabina pv. alisalensis. The $F_{1}$ formed by crossing the resistant parent G30988 to susceptible PI212594 exhibited a mean diseased leaf area of $13.9 \%$, with ratings ranging from 7.5 to $17.5 \%$. Disease severity ratings of plants in the three segregating populations $\left(\mathrm{F}_{2}\right.$, susceptible backcross, and resistant backcross) were widely distributed, with ratings of 0 to $70 \%$ in the $\mathrm{F}_{2}, 0$ to $59 \%$ in the resistant backcross, and 0 to $80 \%$ in the susceptible backcross (Fig. 2). Both the $F_{2}$ and resistant back-
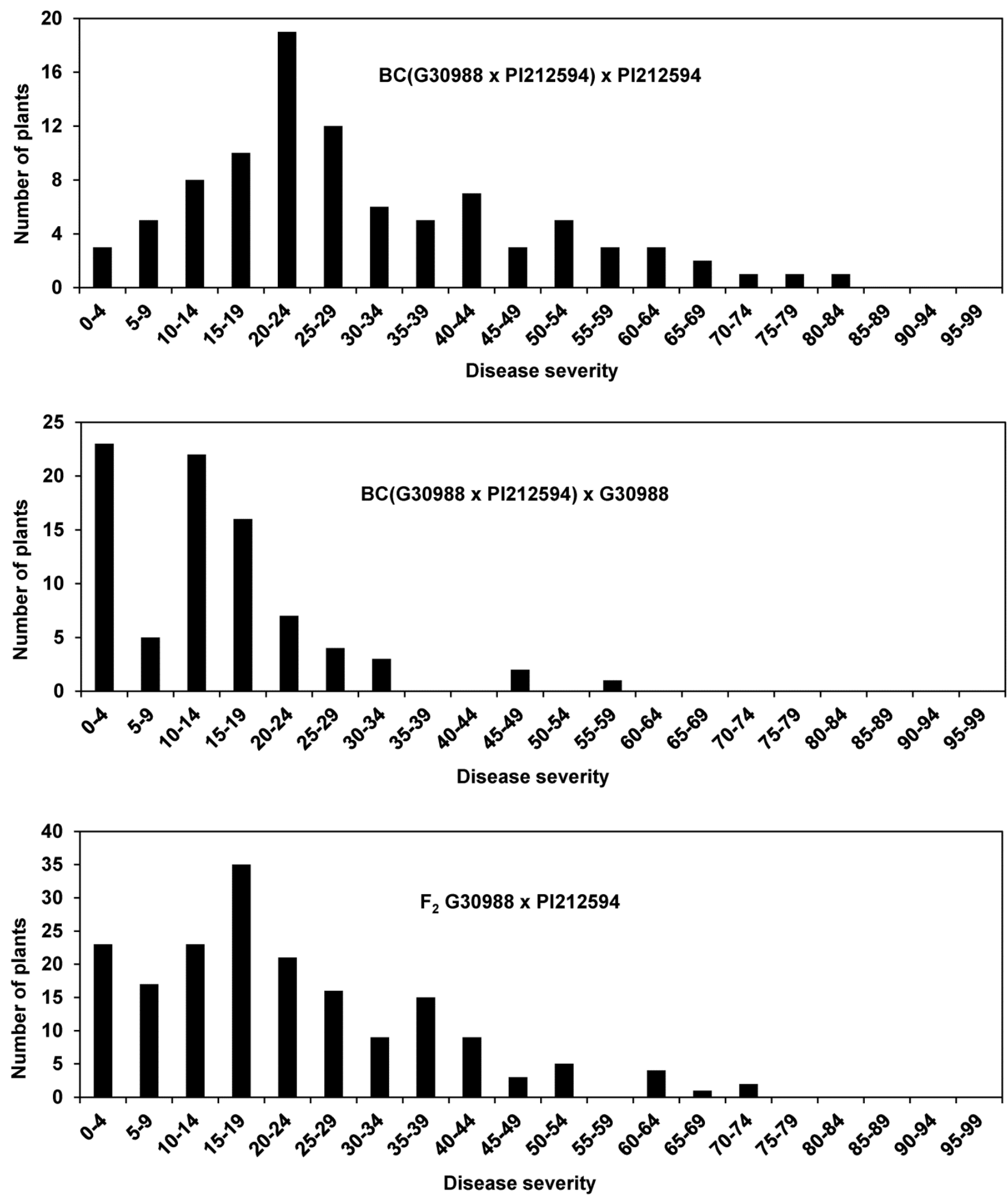

Fig. 2. Distributions of disease severity among $F_{2}$ and backcross populations from the bacterial blight-resistant Brassica juncea G30988 and a bacterial blight-susceptible, rapid-cycling $B$. juncea plant introduction (PI)212594. Disease severity was calculated as the average of percent diseased leaf area between two leaves per plant. 
cross populations exhibited distributions that showed a low point at ratings 5 to $9 \%$ (Fig. 2).

In consultation with local brassica greens growers in South Carolina, it was determined that a product with $10 \%$ or greater leaf blight disease symptoms would not be considered harvestable. Because a large part of their product is pre-cut and bagged, leaves with less than $10 \%$ disease symptoms can be carefully processed and, thus, usable for pre-cut sales. Based on these consultations and no previous determination of resistance in terms of this crop and disease, we deemed $9.0 \%$ leaf infection to be a critical point in analyzing the segregating populations. In addition, in a very few instances, individual G30988 plants had a high score of $9 \%$ disease. Thus, ratings lower than or equal to 9.0\% were considered to be resistant and anything higher to be susceptible. Classifying individuals as resistant or susceptible allowed us to perform a discreet analysis and provided a method to test for relatively simple genetic control of resistance. In general, the observed frequencies of disease severity ratings in the $\mathrm{F}_{2}$ and backcross populations suggested recessive inheritance. The $F_{2}$ population formed by crossing G30988 to PI212594 exhibited frequencies that fit a single-gene model for resistance, with approximately one-quarter of the $F_{2}$ exhibiting a resistant phenotype. With the resistant backcross population, the observations did not fit the model because fewer resistant individuals than expected were observed (Table 3). For a singlerecessive-gene model, the susceptible backcross should contain no resistant individuals but eight were actually identified in this study (Table 3 ).

With a model of two independent, recessive genes controlling resistance, there would be an expectation for $1 / 16$ of the $F_{2}$ and $1 / 4$ of the resistant backcross to exhibit resistance. Using that model, the expected ratio of the $\mathrm{F}_{2}$ did not fit because they exhibited a greater number of resistant individuals than would be expected. However, the recessive backcross population did fit the two-gene model.

Distributions of disease severity ratings in $F_{2}$ and backcross populations made from a cross between G30988 and PI432377 mirror the distributions for the first cross (Fig. 3). In the case of the second cross, the $\mathrm{F}_{1}$ exhibited a mean rating of $18.1 \%$, which was much like the susceptible parent's mean rating of $22.0 \%$. Although the $\mathrm{F}_{2}$ distribution did not exhibit a low point for plants rated 5 to $9 \%$, the resistant backcross population did show a lower frequency at this rating (Fig. 3). As with the previous populations, using $9.0 \%$ as a critical disease rating, one-quarter of the $F_{2}$ population exhibited a resistant phenotype. Additionally, for this population set, the resistant backcross population fit the model closely (Table 3). Only three resistant individuals were observed in the susceptible backcross.

\section{Discussion}

Results of this study verify that certain resistant accessions of $B$. juncea and $B$. rapa, previously identified in artificial inoculation tests in a greenhouse environment (17), express similar high levels of resistance in field environments. Two B. juncea accessions, G30988 and PI418956, and one B. rapa accession, G30499, had lower disease severity ratings and higher healthy leaf yields than other accessions tested, including several cultivars. Of particular interest is G30988, which can be considered highly resistant, exhibiting disease severity ratings near zero in field tests wherein many tested accessions were severely damaged. G30988 also exhibited the highest healthy leaf yields of all genotypes tested in the same field trials. In addition, G30988 is very similar in size, shape, and taste to the susceptible Florida Broadleaf (data not shown); thus, the resistance might be easily introgressed into a commercially acceptable line.

The two primary measures of resistance evaluated in the field trials, disease severity rating and healthy leaf weight, were significantly and negatively correlated with one another. This would indicate that resistance can be identified prior to harvest or, alternatively, gauged at time of harvest or maturity. Either assessment should work to identify relatively resistant individuals or varieties.

Identification of individuals with field resistance to bacterial blight should prove invaluable. The geographic distribution of this disease appears to be expanding and when it emerges in an area it can be extremely damaging, sometimes destroying entire plantings (J. P. Smith, personal communication). As in the current study, $B$. rapa Tendergreen was susceptible to most isolates of Pseudomonas recovered from leafy brassica greens in Oklahoma (19). In contrast, B. juncea Southern Giant Curled mustard green was affected by fewer isolates than Tendergreen, and symptoms were less severe on Southern Giant Curled than on Tendergreen. A similar difference between these two cultivars and species was observed in both years in South Carolina with $P$. cannabina pv. alisalensis isolate TC3. Likewise, Southern Giant Curled, Topper, and Alamo were susceptible to Pseudomonas isolates recovered from collard and turnip green in Ohio (12).

Evaluation of segregating populations developed by crossing G30988 with two different susceptible parents to determine genetic inheritance produced results that were suggestive of resistance controlled by a recessive gene or genes. The data best fit a singlegene model, although not perfectly; one $\mathrm{F}_{2}$ population fit the model while one did not. Whereas both resistant backcross populations did fit the single-gene model, the susceptible backcross populations contained resistant individuals, something not predicted by the model. This may be due to a combination of possible escapes

Table 3. Segregation in progenies from crosses between resistant (R) brassica G30988 and susceptible (S) brassica PIs PI212594 and PI432377 after inoculation with bacterial pathogen Pseudomonas cannabina pv. alisalensis ${ }^{\mathrm{w}}$

\begin{tabular}{|c|c|c|c|c|c|c|}
\hline \multirow[b]{2}{*}{ Parents and crosses } & \multicolumn{2}{|c|}{ Expected ratio } & \multicolumn{2}{|c|}{ Observed (number) } & \multirow[b]{2}{*}{$\chi^{2 \mathrm{x}}$} & \multirow[b]{2}{*}{$P^{\mathbf{y}}$} \\
\hline & $\mathbf{R}$ & $\mathbf{S}$ & $\mathbf{R}$ & $\mathbf{S}$ & & \\
\hline PI212594 & 0 & 18 & 0 & 18 & $\ldots$ & $\ldots$ \\
\hline G30988 & 17 & 0 & 17 & 0 & $\ldots$ & $\ldots$ \\
\hline F1 G30988 × PI212594 & 0 & 17 & 0 & 17 & $\ldots$ & $\ldots$ \\
\hline F2 G30988 × PI212594 & 46 & 137 & 40 & 143 & 1.05 & $0.306^{\mathrm{z}}$ \\
\hline BC(G30988 × PI212594) × G30988 & 41 & 42 & 28 & 55 & 8.15 & 0.004 \\
\hline $\mathrm{BC}(\mathrm{G} 30988 \times \mathrm{PI} 212594) \times \mathrm{PI} 212594$ & 0 & 94 & 8 & 86 & $\ldots$ & $\ldots$ \\
\hline PI432377 & 0 & 8 & 0 & 8 & $\ldots$ & $\ldots$ \\
\hline G30988 & 8 & 0 & 8 & 0 & $\ldots$ & $\ldots$ \\
\hline F1 G30988 × PI432377 & 0 & 8 & 0 & 8 & $\ldots$ & $\ldots$ \\
\hline F2 G30988 × PI432377 & 20 & 60 & 27 & 53 & 3.26 & 0.071 \\
\hline BC( G30988 × PI432377) × G30988 & 20 & 20 & 18 & 22 & 0.4 & 0.527 \\
\hline BC ( G30988 × PI432377) $\times$ PI 432377 & 0 & 40 & 3 & 37 & $\ldots$ & $\ldots$ \\
\hline
\end{tabular}

${ }^{\mathrm{w}} \mathrm{R}=$ plant is resistant (disease severity $\leq 9 \%$ ) and $\mathrm{S}=$ plant is susceptible (disease severity $>9 \%$ ).

${ }^{x}$ Critical $\chi^{2}$ value $=3.841$ at $P=0.05$

${ }^{y}$ Probability values higher than 0.05 indicate nonsignificant values of $\chi^{2}$.

${ }^{\mathrm{z}}$ Significant $\chi^{2}$ at $P<0.01$. 

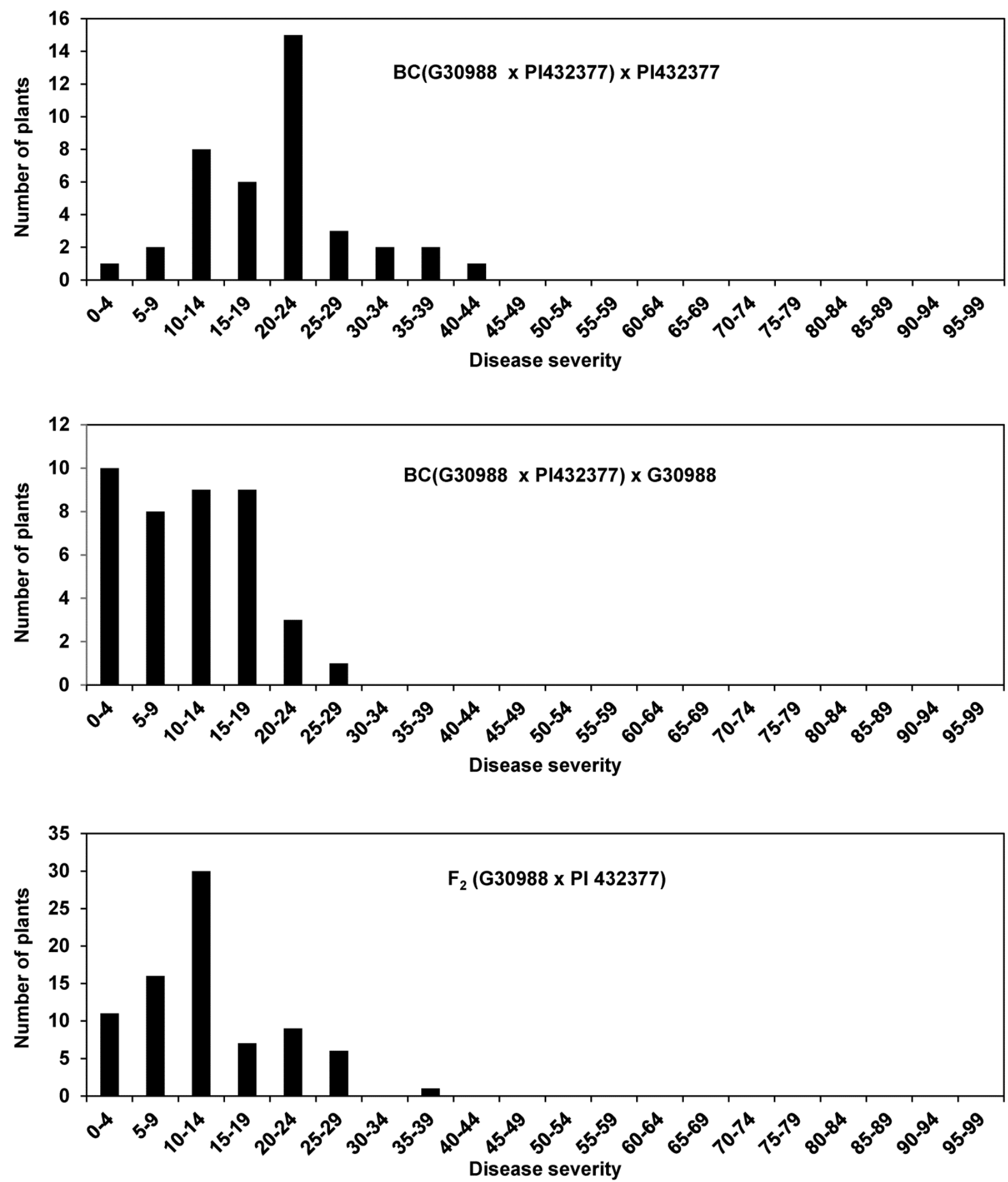

Fig. 3. Distributions of disease severity among $F_{2}$ and backcross populations from the bacterial blight-resistant Brassica juncea G30988 and a bacterial blight-susceptible, rapid-cycling $B$. juncea plant introduction (PI)432377. Disease severity was calculated as the average of percent diseased leaf area between two leaves per plant.

or the presence of modifier genes in one or both of the susceptible parents. Regardless of how the data are interpreted, the likelihood is high that resistance is controlled by a single or small number of recessive genes. What is clear from the studies described herein it that it will be possible to identify resistant individuals in $\mathrm{F}_{2}$ populations that are relatively small in size (e.g., 100 to 200 individuals). It should then be feasible to self-pollinate such selections and develop uniform lines that express a similar high level of resistance. G30988 exhibits some attributes similar to Florida Broadleaf. Hybridization of G30988 and Florida Broadleaf is a logical first step to develop a new mustard green cultivar with high levels of re- sistance to bacterial blight, while maintaining many of the cultivar's desirable horticultural characteristics.

\section{Literature Cited}

1. Bull, C. T., and du Toit, L. J. 2009. First report of bacterial blight on conventionally and organically grown arugula in Nevada caused by Pseudomonas syringae pv. alisalensis. Plant Dis. 93:109-109.

2. Bull, C. T., Manceau, C., Lydon, J., Kong, H. N., Vinatzer, B. A., and Fisher-Lesaux, M. 2010. Pseudomonas cannabina pv. cannabina pv. nov., and Pseudomonas cannabina pv. alisalensis (Cintas Koike and Bull, 2000) comb. nov., are members of the emended species Pseudomonas cannabina (ex Sutic \& Dowson 1959) Gardan, Shafik, Belouin, Brosch, Grimont \& 
Grimont 1999. Syst. Appl. Microbiol. 33:105-115.

3. Bull, C. T., Mauzey, S. J., and Koike, S. T. 2010. First report of bacterial blight of Brussels sprouts (Brassica oleracea var. gemmifera) caused by Pseudomonas cannabina pv. alisalensis in California. Plant Dis. 94:13751375 .

4. Cintas, N. A., Koike, S. T., and Bull, C. T. 2002. A new pathovar, Pseudomonas syringae pv. alisalensis pv. nov., proposed for the causal agent of bacterial blight of broccoli and broccoli raab. Plant Dis. 86:992-998.

5. Keinath, A. P., DuBose, V. B., May, W. H., III, and Wechter, W. P. 2007. Evaluation of biopesticides to manage bacterial leaf spots on turnip greens. Plant Dis. Manage. Rep. 1:V104.

6. Keinath, A. P., Wechter, W. P., and Smith, J. P. 2005. First report of bacterial leaf spot on leafy Brassica greens caused by Pseudomonas syringae pv. maculicola in South Carolina. Plant Dis. 90:683.

7. Kemble, J. M., Ivors, K., Louws, F. J., Jennings, K. M., and Walgenbach, J. F., eds. Rev. 2012. Southeastern U.S. 2012 Vegetable Crop Handbook. Vance Publishing Corp., Lincolnshire, IL.

8. Koike, S. T. 2000. Bacterial blight, a new disease of broccoli caused by Pseudomonas syringae in California. Plant Dis. 84:370.

9. Koike, S. T., Henderson, D. H. Azad, H. R., and Cooksey, D. A. 1998. Bacterial blight of broccoli raab: a new disease caused by a pathovar of Pseudomonas syringae. Plant Dis. 82:727-731.

10. Koike, S. T., Kammeijer, K., Bull, C. T., and O'Brien, D. 2006. First report of bacterial blight of Romanesco cauliflower (Brassica oleracea var. botrytis) caused by Pseudomonas syringae pv. alisalensis in California. Plant Dis. 90:1551-1551.

11. Koike, S. T., Kammeijer, K., Bull, C. T., and O'Brien, D. 2007. First Report of Bacterial Blight of Rutabaga (Brassica napus var. napobrassica) Caused by Pseudomonas syringae pv. alisalensis in California. Plant Dis. 91:112.

12. Lewis Ivey, M. L., Wright, S., and Miller, S. A. 2001. Report of bacterial leaf spot on collards and turnip leaves in Ohio. Plant Dis. 86:186.

13. Olson, S. M., Simonne, E. H., Stall, W. M., Vallad, G. E., Webb, S. E., and Smith, S. A. 2011. Cole crop production in Florida. Pages 55 to 77 in: Vegetable Production Handbook for Florida. S. M. Olson and B. Santos, eds. Fla. Coop. Ext. Serv. Univ. Fla. Gainesville.

14. Orton, T. J., Ghidiu, G. M., Hamilton, G. C., Majek, B. A., Wyenandt, C. A. and Dugan, D., eds. 2011. Commercial Vegetable Production Recommendations. New Jersey. Rutgers Coop. Ext. Serv. Rutgers, State University of New Jersey, New Brunswick.

15. Smith, J. P., and Keinath, A. P. 2004. Crop profile for leafy greens and collards (fresh market) in South Carolina. National Information System for the Regional Integrated Pest Management Centers, North Carolina State University, Raleigh.

16. United States Department of Agriculture, National Agricultural Statistics Service. 2004. Vegetable Summary.

17. Wechter, W. P., Farnham, M. W, Smith, J. P, Keinath, A. P. 2007. Identification of Resistance to peppery leaf spot among Brassica juncea and Brassica rapa plant introductions. HortScience 42:1140-1143.

18. Wechter, W. P., Keinath, A. P., Farnham, M. W., and Smith, J. P. 2010. First report of bacterial blight on broccoli and cabbage caused by Pseudomonas syringae pv. alisalensis in South Carolina. Plant Dis. 94:132.

19. Zhao, Y. F., Damicone, J. P., Demezas, D. H., Rangaswamy, V., and Bender, C. L. 2000. Bacterial leaf spot of leafy crucifers in Oklahoma caused by Pseudomonas syringae pv. maculicola. Plant Dis. 84:1015-1020. 